\title{
Cost Efficiency and Default Risk in Commercial Banks in Kenya
}

\author{
Oduor Joseph Atieno $^{1} \quad$ Dr. Tobias Olweny ${ }^{2} \quad$ Dr. Julius Miroga ${ }^{3}$ \\ School of Business \& Entrepreneurship, Jomo Kenyatta University of Agriculture \& Technology, \\ PO box 62000 - 00200, Nairobi, Kenya
}

\begin{abstract}
The purpose of this study was to evaluate effect of cost efficiency on default risk in commercial banks in Kenya. Many literature show that there have been an increased number of significant bank problems in USA, Brazil, India, Pakistan Indonesia, Ghana and even Kenya. In Kenya, the ratio of gross non-performing loans to gross loans increased from 6.8 percent in December 2015 to 9.2 percent in December 2016, subsequently increasing the default risk. The banking sector in Kenya has undergone several changes from the early 1990's that was characterized by high level of bank failures, non-performing loans and inefficiencies to the current period that exhibits high levels of profitability, innovations like mobile and internet banking, agency banking, unsecured lending and the introduction of credit reference bureaus. The National treasury had hinted at introducing regulations to curb the high interest rate regime after commercial banks recorded huge profit margins in a high interest rate environment, even though depositors had been left dry. According to the bank supervisory report, the interest rate spread widened to 13 per cent at the end of December 2011 from 10.3 per cent by December 2010 which the CBK Governor termed as a sign of inefficiency in the banking sector. Secondary data was used in the study and descriptive survey design was applied. The target population was 42 Commercial Banks in Kenya out of which 2 were under receivership and 1 was under statutory management. Panel data for 39 commercial banks for the six years period from 2014 to 2019 were obtained from the CBK and individual bank websites. The study was guided by Agency theory, Moral hazard theory and Stakeholders theory. Descriptive statistics, correlation analysis and random and fixed effects were used for secondary data using E-views software. The findings indicated that cost efficiency highly reduces loan defaults. It was recommended that cost efficiency be improved in all commercial banks to reduce loan defaults.
\end{abstract}

Keywords: Cost efficiency, Default Risk

DOI: $10.7176 / \mathrm{RJFA} / 12-22-06$

Publication date: November 30th 2021

\section{Introduction}

Banking sector plays a key role in the development of an economy. The development role undertaken by the banking sector determines the step for development of an economy. Hence the stability of banking sector is key for the development of an economy. The primary function of a bank is to mobilize deposits from surplus units to deficit units in the form of loan and advances to various sectors such as agricultural, industrial and governments. However, in recent times, the banks have become very cautious in extending loans due to non-performing assets (Sontakke \& Tiwari, 2013).

The measurement of bank efficiency plays a pivotal role in the accurate assessment of the performance of individual banks and the industry as a whole, while providing information concerning the overall stability of the entire financial system. Inefficiencies in the banking industry can cause banking crisis and impede economic growth since they are the main financial intermediation channels. Similarly, risk is an important determinant of financial stability. Miss-assessment of risk has several repercussions including bank failure, stifling money supply and credit flow, losses for investors and depositors, banking crisis and destabilization of the financial service industry (Sarpong \& Winful, 2017).

Banks that properly control their operating costs, embrace good human resource practices that improve productivity and invest in viable projects will have high profitability which leads to increased bank efficiency and decreased default risk (Sarpong D. (Jnr.) \& Winful C. E. , 2017). The banking sector in Kenya has undergone several changes from the early 1990's that was characterized by high level of bank failures, high default rates and inefficiencies to the current period that exhibits high levels of profitability, innovations like mobile and internet banking, agency banking, unsecured lending and the introduction of credit reference bureaus. However, high levels of default are still being experienced in the Kenyan banking sector.

During the year 2013, bad loans jumped by $30.9 \%$ to hit Kshs 80.6 billion, the highest in over six years, even outpacing growth in new credit advanced by the lenders hence crippling the development of the economy (Ngigi, 2014). In Kenya, the ratio of gross non-performing loans to gross loans increased from 6.8 percent in December 2015 to 9.2 percent in December 2016, subsequently increasing the default risk (Oyuke, 2012). According to the bank supervisory report, the interest rate spread widened to 13 per cent at the end of December 2011 from 10.3 per cent by December 2010 which the CBK Governor termed as a sign of inefficiency in the banking sector (CBK, 2011). Many researchers have analyzed default risk based on variables such as credit policy, interest rates, while 
bank efficiency has been overlooked. It is on this basis that the study seeks to establish the effect of bank efficiency on default risk in Commercial Banks in Kenya

\section{Literature Review}

Independent Variable

\section{Cost Efficiency}

- Operating cost to total Asset ratio

- Total loan to total asset raio

- Total loan to total deposit ratio
Figure 1. Conceptual Framework

Dependent Variable

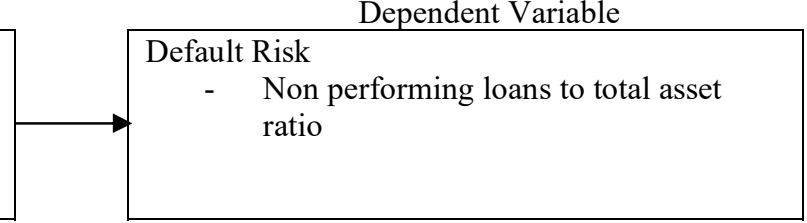

\subsection{Theoritical Review}

The study was structured on; Agency theory, Moral hazard theory and Stakeholder theory

\subsection{Empirical Literature Review}

(Ferrier M. J. \& Lovell K., 2016) applied both the Data Envelopment Analysis (DEA) and Stochastic Frontier Analysis (SFA) as they tried to measure the cost efficiency level of USA banks. They conducted an explicit comparison between the two methods and discussed the results obtained. They analyzed the cost structure of 575 banks and concluded that the two methods generally drew similar conclusions on the average level of cost efficiency. Nevertheless, the DEA cost efficiency score was higher than that of the SFA. This result was explained by their suggestion that the DEA frontier was considered sufficiently flexible to envelop the data more closely than the SFA frontier. When they decomposed the cost inefficiency into the technical and allocative inefficiency, both techniques led to different conclusions. The magnitudes of both the technical and allocative inefficiency scores gave different results. In addition, the rank correlation coefficients between the DEA and SFA technical efficiency and cost efficiency were 0.014 and 0.017 respectively. They were found not to be significantly different from zero. Therefore, it was concluded that the efficiencies derived from both the DEA and SFA did not give consistent rankings. (Resti, 2017) further provided evidence on the efficiency levels of the Italian banking sector. He formulated a sample of 270 Italian banks and applied the use of both the parametric (SFA) and non-parametric (DEA) frontier techniques to examine the banks cost efficiency level. It was observed that the mean efficiency score ranged between $66 \%$ and $76 \%$ under both the DEA and SFA. In addition, there was a very high positive correlation for the score rankings between the two methods. Therefore, (Resti, 2017) concluded that both the DEA and SFA methods do not differ substantially. Nevertheless, it was reported that there was an efficiency gap that existed especially when the efficiency values were grouped into different classes of geographical area and bank size.

(Drake L. \& Weyman T. G., 2017) used both the parametric (SFA) and non-parametric (DEA) techniques to estimate the cost efficiency level of 46 British building societies. It was observed that the cost inefficiency level in the British building society sector were of the order of $12 \%$ to $13 \%$ for parametric and non-parametric techniques respectively. In addition, there was a high rank correlation order between the two sets of efficiency scores.

In a comprehensive study of bank efficiency level in the USA, (Bauer P. W., Berger A. N., Ferrier G. D. \& Humphrey D. B., 2018) applied the use of four frontier approaches. They included: the Stochastic Frontier Analysis (SFA), Distribution Free Approach (DFA), Thick Frontier Approach (TFA) and the Data Envelopment Approach (DEA). They formulated a panel of 683 large US banks over a period of 12 years from 2005-2017. (Bauer et al, 2018) found out that the mean cost efficiency of the parametric models were higher in comparison to the nonparametric models. It was observed that the parametric models had an average of $83 \%$ and the non-parametric models averaged at $30 \%$. In addition, the average rank correlation between the DEA and the parametric techniques was $10 \%$. This suggested that the parametric and non-parametric approaches gave very weak consistency in their efficiency scores. (Bauer et al, 2018) also observed that the identification that was done between the best and the worst practicing banks was not consistent between the DEA and the parametric techniques. However, there were similarities in the distributional characteristics between the efficiency scores and the efficiency rank correlation.

It was generally observed that all the approaches were stable over time although the DEA approach had slightly better stability than the parametric techniques. However, it was concluded that the parametric technique appeared more consistent with competitive conditions in the market. This was argued to be true as economic theory stipulates that competition drives out of the market the most inefficient banks. Therefore, the banks that are left in the market in the long run should be reasonably efficient. Finally, it was argued that the parametric methodologies seemed to be consistent with the standard non-frontier performance measures, i.e. the financial ratios. Nevertheless, the non-parametric measures were in contrast to this observation, as they were weakly related to the financial ratio performance measures.

In estimating the cost efficiencies of a sample of 254 large banks in the US, (Eisenbeis R.A., Ferrier G.D. \& 
Kwan S.H., 2017) applied the use of both a Stochastic Frontier Approach (SFA) and Linear Frontier Approach (LFA). They applied the two techniques in order to compare the robustness of the results obtained. The study period was from 2011-2016 It was observed that the DEA inefficiency scores were two or three times larger than those generated by SFA. The average of those generated by the DEA was $30 \%$ against $15 \%$ for SFA. When the banks were classified into various size-based quartiles, they found out that the level and variation of small banks inefficiency scores were on average higher than those of large banks. Inefficiencies were observed to persist over time. Nevertheless, it was observed that the persistence results for the linear programming estimates (DEA) were significantly greater than those of the econometric estimates (SFA). Moreover, the efficiency rank-order correlations between the two approaches ranged from a low of 0.44 to a high of 0.58 .

(Eisenbeis et al, 2017) in their study, concluded that there were significant differences between the efficiency measures derived from both the DEA and SFA techniques. Both techniques examined the relationship between bank cost efficiency and their risk taking behavior, managerial competence and stock price return behavior. It was concluded that both the parametric and non-parametric efficiency estimates produced reasonable and informative efficiency scores. Nevertheless, it was argued that the SFA estimates should be given more weight in the assessment of the banking efficiency than those provided by the DEA methodology.

(Mendes V. \& Rebelo J., 2017), in a study of the variable cost efficiency of the Portuguese banking sector from 2011 until 2016, the time period of strong transformations that followed the entry of Portugal into the European Community. The empirical results indicate a substantial variability in the efficiency levels of Portuguese banks, with some institutions having significantly higher levels of variable cost efficiency than others. The average cost inefficiency level is around $5.7 \%$ for the whole period. Their results also indicate that inefficiency scores tend to be stable or even increase slightly across the period 2011-2016. Therefore, (Mendes V. \& Rebelo J., 2017) argue that the increasing competition on the financial markets that followed the entry of Portugal into the European Community has not led to the expected increase of efficiency levels.

Recently, (Casu B., Girardone C.. \& Molyneux P., 2015) while determining the cost characteristics, profit efficiency and productivity change of the Italian conglomerates applied the use of three frontier models. They included: the Data Envelopment Analysis (DEA), Stochastic Frontier Analysis (SFA) and Distribution Free Approach (DFA). They used a sample of Italian banking groups and established an unbalanced panel from the year 2011-2014. It was observed that the efficiency measures from the stochastic and deterministic frontiers were reasonably similar in magnitude and variation in the efficiency level. The standard deviation was around $10 \%$. In addition, the DEA trend of cost efficiency was increasing between 2011 and 2014. It was also observed that there was a sharp decline in cost efficiency in 2014. Nevertheless, the SFA estimates exhibited a steady improvement in the cost efficiency. It was also observed that the DFA efficiency estimates were consistent with the DEA scores rather than the SFA. In addition, the DFA displayed a decreasing trend in efficiency level.

(Becalli E., Casu B. \& Girardone C., 2016) Measured the cost efficiency of the stock market listed in European banks between the year 2014 and 2015. They investigated the link between the efficiency measures and the market performance of financial institutions by the use of the mean measures of SFA and DEA. They found out that the percentage changes in stock prices reflected in the cost efficiency, particularly the percentages derived from the DEA technique. Furthermore, the SFA efficiency scores were slightly higher than the DEA scores. This was $85 \%$ against $83 \%$ respectively. The DEA efficiency scores were also more dispersed than those of the SFA technique. Majority of the empirical papers discussed on SFA technique have applied the the model for data analysis (Battese G.E. \& Coelli T., 2015). It is a translog cost function that is considered to be a suitable frontier estimation technique that captures the dynamic changes of the cost function over time.

The optimal cost function derived represents a long run equilibrium relationship between total costs on onehand and outputs and input prices on the other. In this regard this research paper extends the use of the SFA model using the (Battese \& Coelli, 2015) model.

(Staikouras C., Mamatzakis E. \& Koutsomanoli-Filippaki A., 2018) Assess the cost efficiency of banks operating in six emerging South Eastern European (SEE) countries: Bosnia-Herzegovina, Bulgaria, Croatia, FYR of Macedonia, Romania and Serbia-Montenegro over the period 2009-2015. Using a stochastic frontier approach, the authors find existence of low level of cost efficiency, with significant inefficiency differences among countries. They observe that foreign banks and banks with higher foreign bank ownership have the least inefficiency. In addition, they notice that cost inefficiency is negatively related to bank capitalization. However, they identify a positive but insignificant relationship between cost inefficiency and credit risk. Gross Domestic Product (GDP) growth has a positive relationship with inefficiency.

(Bonin J.P., Hasan I. \& Wachtel P., 2014) Examined the effects of ownership on bank efficiency for eleven transition countries over the period 2006 to 2010, using SFA. Their findings revealed that foreign banks are more cost-efficient than other banks. Moreover, bank size was found to be negatively correlated with efficiency.

(Fries S. \& Taci A., 2015) investigated cost efficiency of banks in 15 East European countries over the period 2005 to 2012. The results showed that private banks are more efficient than state-owned banks. The authors underlined the non-linear association between a country`s progress in banking reform and cost efficiency. 
(Yildirim H. S. \& Philippatos G. C., 2017) studied cost and profit efficiency of banks in 12 transition countries over the period 2007 to 2014. The results indicated that foreign banks were more cost-efficient but less profitefficient relative to state-owned and private domestic banks.

(Borovicka, 2017) investigated the relationship between efficiency and cost efficiency in 19 European transition economies. The results indicated that the cream skimming effect is significant, which implies that foreign investors tend to acquire the most cost efficient banks in the first place.

(Fang Y., Hasan I. \& Marton K., 2016) Examined cost and profit efficiency and their determinants in six transition countries of South-Eastern Europe over the period 2004 to 2014 . The results revealed a higher efficiency for foreign banks and the fact that the degree of individual banks' competitiveness and institutional development are positively associated with cost and profit efficiency.

(Podpiera A. \& Podpiera J., 2015) Analyzed the relationship between banks cost efficiency and bank failures using data for Czech banking sector over the period 2004 to 2013. The results showed that cost inefficient management was a predictor of bank failures during the years of banking sector consolidation. The authors suggested suggest the inclusion of cost efficiency in early warning Systems.

(Asaftei G. \& Kumbhakar S. C., 2018) analyzed the relationship between cost efficiency and the regulation implemented by central bank in Romania over the period 2006 to 2012 using both SFA and shadow cost functions. The results revealed that the cost of technical inefficiency decreased in the years following tightening of regulation.

(Asaftei \& Kumbhakar, 2018) on Italian banks over the period 2013-2016 the aftermath of the introduction of the EU's 1992 Single Market Programme, the authors found improvement in the overall cost efficiency of the Italian banking system. The study also examines the key factors explaining the Italian banks' cost efficiency and find evidence that there is no association between size and bank efficiency.

\section{Research Methodology 3.1 Research Design}

The study adopted descriptive survey research design to meet its research objectives. This was appropriate in this study since surveys are useful in describing the characteristics of a large population. No other research method can provide this broad capability, which ensures a more accurate sample to gather targeted results from which to draw conclusions and make important decisions.

\subsection{Target population}

The target population was all the 42 Commercial Banks in Kenya as at 2019 by Central Bank of Kenya (CBK, 2020).

\subsection{Data collection Instruments}

Secondary data was collected using audited and published financial statements from the websites of the Central Bank of Kenya to establish the relationship between bank efficiency and default risk in commercial banks in Kenya.

\subsection{Data Collection Procedure}

Panel data technique for a period of six years from 2014 to 2019 was employed to determine the effect of bank efficiency on default risk in commercial banks in Kenya. Secondary data was collected from the Central Bank of Kenya website as well as from the websites of the individual commercial banks. Audited and published Financial Statements for the period 2014 to 2019 were obtained from the Central Bank of Kenya websites and also from the websites of the individual commercial banks.

\subsection{Data Analysis and Presentation}

Data was analyzed using E-views software. Model specification estimation and rationale of variables was done. Secondary data was tested for normality and transformed into natural logarithm before regression was undertaken. Regression co-efficient between the independent and the dependent variable was therefore established. Data was presented using tables.

\subsection{Model Specification and Rationale of variables}

In order to check which variables were highly correlated so as to avoid the problem of multi-collinearity which is a common problem in time series data, correlation analysis was used. The data included time series and crosssectional data that were pooled into a panel data set and then estimated using panel data regression. Data was converted to their natural logs and multiple regression conducted in order to deal with the problem of large numbers and eliminate Heteroscedasticity. This thesis employed multiple panel unit root tests that can be arranged in groups by cross section dependence or independence homogenous, or heterogeneous unit roots that are defined by (Im Pesaran \& Shin, 2003) \& (Levin et al, 2002). Individual unit root has limited powers hence the probability of 
rejecting null hypothesis when it's false. Common unit root process Levin, Lin and Chu panel unit root test was used and for individual unit root process the thesis used three types of panel unit root tests, Im, Pesaran and Shin panel unit root test, ADF-Fisher chi-square test and the Phillips-Perron -Fisher Chi square panel unit root test.

\section{Results and Discussion}

\subsection{Natural Log of Non-Performing Loans}

Evaluation of stationarity of the variables in the model was done using multiple unit root tests which were most applicable for unbalanced panels. Stationary means the variance mean, and autocorrelation of a variable does not change with time. All panel unit root tests have null hypothesis tests of non-stationary bank efficiency and nonperforming loans. The natural log of NPL was found to be stationary at intercept and level I (0) because the Levin, Lin \& Chu t* had a probability value of 0.0000 which is significant at $5 \%$ level of significance. Therefore, we reject the null hypothesis that LN NPL has a unit root. Im, Pesaran and Shin unit root test, Augmented DickieFuller ADF-Fisher Chi-square, Phillips-Perron Fisher Chi square, were also implemented which confirm stationary data since the probability is less than 0.005 .

Panel unit root test: Summary

Series: LN NPL

Sample: 20142019

Exogenous variables: Individual effects

Automatic selection of maximum lags

Automatic lag length selection based on SIC: 0

Newey-West automatic bandwidth selection and Bartlett kernel

Table 1: Unit Root Test for LN_NPL

\begin{tabular}{|c|c|c|c|c|}
\hline Method & Statistic & Prob.** & $\begin{array}{c}\text { Cross- } \\
\text { sections }\end{array}$ & Obs \\
\hline \multicolumn{5}{|c|}{ Null: Unit root (assumes common unit root process) } \\
\hline Levin, Lin \& Chu t* & -23.0661 & 0.0000 & 36 & 175 \\
\hline \multicolumn{5}{|c|}{ Null: Unit root (assumes individual unit root process) } \\
\hline Im, Pesaran and Shin W-stat & -4.31649 & 0.0000 & 35 & 172 \\
\hline ADF - Fisher Chi-square & 123.366 & 0.0002 & 36 & 175 \\
\hline PP - Fisher Chi-square & 157.115 & 0.0000 & 36 & 175 \\
\hline
\end{tabular}

** Probabilities for Fisher tests are computed using an asymptotic Chi -square distribution. All other tests assume asymptotic normality.

\subsection{Natural log of Loans to Assets}

The Levin, Lin \& Chu t* statistic, Im, Pesaran and Shin unit root test, Augmented Dickie-Fuller ADF-Fisher Chisquare, Phillips-Perron Fisher Chi square show probability of less than 0.005 for LN_LA .Therefore, we reject the null hypothesis that LN_LA has a unit root.

Panel unit root test: Summary

Series: LN LA

Sample: 20142019

Exogenous variables: Individual effects

Automatic selection of maximum lags

Automatic lag length selection based on SIC: 0

Newey-West automatic bandwidth selection and Bartlett kernel

Table 2: Unit Root Test for LN_LA

\begin{tabular}{|c|c|c|c|c|}
\hline Method & Statistic & Prob.** & $\begin{array}{l}\text { Cross- } \\
\text { sections }\end{array}$ & Obs \\
\hline \multicolumn{5}{|c|}{ Null: Unit root (assumes common unit root process) } \\
\hline Levin, Lin \& Chu t* & -8.98687 & 0.0000 & 36 & 177 \\
\hline \multicolumn{5}{|c|}{ Null: Unit root (assumes individual unit root process) } \\
\hline Im, Pesaran and Shin W-stat & 0.03525 & 0.5141 & 36 & 177 \\
\hline ADF - Fisher Chi-square & 72.4656 & 0.4624 & 36 & 177 \\
\hline PP - Fisher Chi-square & 106.740 & 0.0049 & 36 & 177 \\
\hline
\end{tabular}


** Probabilities for Fisher tests are computed using an asymptotic Chi

-square distribution. All other tests assume asymptotic normality.

4.3 Natural log of Loans to Deposit

The natural log of LD was found to be stationary because the Levin, Lin \& Chu t*, Im, Pesaran and Shin unit root test, Augmented Dickie-Fuller ADF-Fisher Chi-square, Phillips-Perron Fisher Chi square had probability of less than 0.005. The null hypothesis that LN_LD has a unit root was therefore rejected. This is shown in table 4.7 below.

Panel unit root test: Summary

Series: LN LD

Sample: 20142019

Exogenous variables: Individual effects

Automatic selection of maximum lags

Automatic lag length selection based on SIC: 0

Newey-West automatic bandwidth selection and Bartlett kernel

Table 4.3: Unit Root Test for LN_LD

\begin{tabular}{|c|c|c|c|c|}
\hline Method & Statistic & Prob.** & $\begin{array}{c}\text { Cross- } \\
\text { sections }\end{array}$ & Obs \\
\hline \multicolumn{5}{|c|}{ Null: Unit root (assumes common unit root process) } \\
\hline Levin, Lin \& Chu t* & -10.6672 & 0.0000 & 35 & 173 \\
\hline \multicolumn{5}{|c|}{ Null: Unit root (assumes individual unit root process) } \\
\hline Im, Pesaran and Shin W-stat & -0.95324 & 0.1702 & 35 & 173 \\
\hline ADF - Fisher Chi-square & 82.4823 & 0.1460 & 35 & 173 \\
\hline PP - Fisher Chi-square & 102.367 & 0.0070 & 35 & 173 \\
\hline
\end{tabular}

** Probabilities for Fisher tests are computed using an asymptotic Chi -square distribution. All other tests assume asymptotic normality.

\section{Conclusions and recommendation}

The results lead to a conclusion that there exists a negative and significant relationship between cost efficiency and default rate in commercial banks in Kenya. This implies that when cost efficiency improves, Loan default will reduce significantly. Commercial banks should therefore make deliberate efforts to improve cost efficiency to reduce default risks.

\section{References}

Asaftei G. \& Kumbhakar S. C. (2018). Regulation and efficiency in transition: the case of Romanian banks. Journal of Regulatory Economics, 33, , 253-282.

Battese G.E. \& Coelli T. (2015). A Model for Technical Inefficiency Effects in a Stochastic Frontier Production Function for Panel Data. Empirical Economics (20), 325-332.

Bauer P. W., Berger A. N., Ferrier G. D. \& Humphrey D. B. (2018). Consistency Conditions for Regulatory Analysis of financial Institutions: A comparison of Frontier Efficiency methods. Journal of Economics and Business, Vol. 50 (2), 85-114.

Becalli E., Casu B. \& Girardone C. (2016). Efficiency and Stock Performance in European Banking. Journal of Business and Accounting, Vol. 33 (1-2), 245-262.

Bonin J.P., Hasan I. \& Wachtel P. (2014). Bank performance, efficiency and ownership in transition countries. Bank of Finland Institute for Economies in Transition Discussion, 1-7.

Borovicka, J. (2017). Banking Efficiency and Foreign Ownership in Transition: Is There Evidence of a CreamSkimming Effect? Financial Stability Report, Oesterreichische National Bank (Austrian Central Bank), issue 13, 68-82.

CBK. (2011). Bank Supervision report. Nairobi, Kenya: CBK Publishers.

Drake L. \& Weyman T. G. (2017). Productive and allocative inefficiencies in UK Building societies: A comparison of non-parametric and stochastic frontier Technique. The Manchester School of Economics and Social Studies, 60, 1, 22-37.

Eisenbeis R.A., Ferrier G.D. \& Kwan S.H. (2017). The Informativeness of Stochastic Frontier and Programming Frontier Efficiency Scores: Cost Efficiency and Other Measures of Bank Holding Company Performance. Atlanta: Federal Reserve Bank of Atlanta.

Fang Y., Hasan I. \& Marton K. (2016). Bank efficiency in South Eastern Europe. Economics of Transition, 19, 495-520. 
Ferrier M. J. \& Lovell K. (2016). Measuring Cost Efficiency in Banking: Econometric and Linear Programming Evidence. Journal of Econometrics 46(1-2), 229-245.

Fries S. \& Taci A. (2015). Cost efficiency of banks in transition: Evidence from 289 banks in 15 post- communist countries. Journal of Banking and Finance, 29, 55-81.

Im Pesaran K. \& Shin Y. (2003). Testing for unit roots in hetero- geneous panels. Journal of Econometrics, 115, 53-74.

Levin A., Lin C. \& Chu C. (2002). Unit root tests in panel data: Asymptotic and nite-sample properties. Journal of Econometrics 108, 1-24.

Mendes V. \& Rebelo J. (2017). oductive Efficiency, Technological Change and Productivity in Portuguese banking. Applied Financial Economics, Vol. 9, , 513-521.

Ngigi, G. (2014). High interest rates leave banks with Sh70bn in bad loans:Banks feel the heat of new CBK order on bad loans. Nairobi: Business Daily.

Oyuke, J. (2012). Treasury in new bid to tame rogue banks. The Standard Newspaper.

Podpiera A. \& Podpiera J. (2015). Deteriorating Cost Efficiency in Commercial Banks Signals an Increasing Risk of Failure. Economic Change and Restructuring,41(3), , 209-219.

Resti, A. (2017). Evaluating the cost-efficiency of the Italian banking system: What can be learned from the joint application of parametric and non-parametric techniques. Journal of Banking \& Finance, 21(2), , 221-250.

Sarpong D. (Jnr.) \& Winful C. E. . (2017). Bank efficiency and default risk: The case of Ghana. Journal of Economics and International Finance, 9(6), 44-53.

Sontakke R. \& Tiwari C. (2013). Trend Analysis of Nonperforming Asset in Scheduled Commercial Banks in India. International Journal of Application or Innovation in Engineering \&Management (IJAIEM), ISSN $2319-4847$.

Staikouras C., Mamatzakis E. \& Koutsomanoli-Filippaki A. (2018). An empirical investigation of operating performance in the new European banking landscape. Global Finance Journal 19(1), 32-45.

Yildirim H. S. \& Philippatos G. C. (2017). Efficiency of banks: Recent evidence from the transition economies of Europe, 1993-2000. The European Journal of Finance, 13(2), 123-143. 